Article

\title{
The Road Safety Education Program for Adolescents Using Social Media, Proving Increasing Knowledge, Beliefs, Attitudes, Intentions and Behavior
}

\author{
Intan Zainafree ${ }^{1, * \mathbb{D}}$, Suharyo Hadisaputro ${ }^{2}$, Agus Suwandono ${ }^{3}$ and Bagoes Widjanarko ${ }^{4}$ \\ 1 Department of Public Health, Faculty of Sports Science, Universitas Negeri Semarang, Semarang 50229, \\ Indonesia \\ 2 Department of Internal Medicine, Faculty of Medicine, Diponegoro University, Semarang 50275, Indonesia; \\ prof_haryo@yahoo.co.id \\ 3 Department of Epidemiology, Faculty of Public Health, Diponegoro University, Semarang 50275, Indonesia; \\ suwandono49@gmail.com \\ 4 Department of Health Promotion, Faculty of Public Health, Diponegoro University, Semarang 50275, \\ Indonesia; bagoes62@gmail.com \\ * Correspondence: intanzainafree@gmail.com
}

Citation: Zainafree, I.; Hadisaputro, S.; Suwandono, A.; Widjanarko, B. The Road Safety Education Program for Adolescents Using Social Media, Proving Increasing Knowledge, Beliefs, Attitudes, Intentions and Behavior. Safety 2022, 8, 12. https:// doi.org/10.3390/safety 8010012

Academic Editor: Raphael Grzebieta

Received: 30 December 2021

Accepted: 11 February 2022

Published: 16 February 2022

Publisher's Note: MDPI stays neutral with regard to jurisdictional claims in published maps and institutional affiliations.

Copyright: (c) 2022 by the authors. Licensee MDPI, Basel, Switzerland. This article is an open access article distributed under the terms and conditions of the Creative Commons Attribution (CC BY) license (https:/ / creativecommons.org/licenses/by/ $4.0 /)$.

\begin{abstract}
Deaths due to road traffic accidents (RTA) accounted for $2.46 \%$ of deaths out of the total deaths in Indonesia. Road safety education (RSE), as an effort to prevent RTA, focuses on increasing knowledge; however, variations of techniques, methods, and media are less used. This study aims to analyze the application of RSE innovations that have been compiled based on interests and needs of adolescents, which are expected to be able to increase knowledge, beliefs, attitudes, intentions, and safe driving behavior. This research used a quasi-experimental approach with a non-randomized pre-test-post-test control group design approach. The Zainafree Program intervention model was conducted for 6 weeks on 362 students who were selected using purposive sampling technique at two schools with the same characteristics. The bivariate analysis was conducted to observe the effect of the model on changes in knowledge, beliefs, attitudes, intentions, and behavior. We analyzed multivariately using GLM-RMA to determine the effectiveness of the model from various confounding factors. The Mann-Whitney test in the intervention and control group demonstrated a significant difference in the average post-test score of two on all dependent variables $(p=0.000)$. The results of the GLM-RMA test demonstrated the effect of the Zainafree Program on knowledge ( $p=0.000$; ETA Square $=35.1)$, beliefs $(p=0.000$; ETA Square $=32.0)$, attitudes $(p=0.000$; ETA Square $=50.9)$, intentions $(p=0.000$, ETA Square $=20.7)$, and behavior $(p=0.000$; ETA Square $=28.2)$, after adjusting for involvement between confounding variables $(p=0.000$; ETA Square $=16.2)$, which demonstrated that the intervention was able to explain 16.2 changes that occur in the scores of five aspects together. The RSE program was proven to be successful in increasing students' knowledge, beliefs, attitudes, intentions, and behavior compared to those who did not receive the program.
\end{abstract}

Keywords: road safety education; road traffic accidents; driver education; adolescents; Indonesia

\section{Introduction}

In Indonesia, the road traffic accident (RTA) is one of the complex problems in the transportation system. The incidence of RTA in Indonesia has increased by about $4.87 \%$ per year for the last 5 years [1]. It occurs a lot in urban areas [2]. One of the metropolitan cities in Indonesia with the highest number of RTA is in Semarang. The changes in the community's mobility due to the COVID-19 pandemic in Semarang have not reduced risky driving behavior. This can be observed from the number of RTA in Semarang throughout 2020, which were 939 cases with 152 deaths, 928 injured people, and 387,950,000 rupiah in material losses. Whereas, when compared to other metropolitan cities in the same year, the 
number of accidents in Yogyakarta, for example, was 499 cases with 0 deaths, 603 injuries, and 304,950,000 material losses [3].

The fundamental factors that contribute to RTA are human factors, such as traffic rules violations and driver errors [4]. Adolescents are considered to be the big population at risk of being involved in traffic accidents, especially in motorcycle accidents [5]. Semarang police's data released $73 \%$ of traffic accidents dominated by motorcycles driven by adolescents [3]. The previous research found that $40 \%$ of motorcycle accidents in Jakarta involved adolescents, of which $91.3 \%$ did not have a driver's license [6]. This dominance in traffic accidents by motorcycle riders is accompanied with an increase in motorcycle sales because this mode of transportation is considered cheap and practical [7]. The other risk factors that are significantly associated with motorcycle accidents in adolescents include driving at high speeds, using cell phones while driving, driving drowsy or drunk, fatigue, and psychological distress [6-8].

The substantial focus of reducing the incidence of traffic accidents lies in developing strategies that minimize human error. One of them is the provision of traffic safety education as a form of implementing the "4E: Education, Enforcement, Engineering, Emergency Systems" strategy [8]. The Indonesian government has committed to reducing the risk factors for traffic accidents through a driving safety education in the form of a road safety partnership action (RSPA). One of its flagship programs is the Police Goes to School [9], which is a road safety education activity carried out by the police by giving lectures at a large student forum once a year with a duration of $60 \mathrm{~min}[10,11]$. Although considered a superior program, this program has not been able to reduce the number of traffic accidents in adolescents. The causes include the receipt of incomplete driving safety information, as most programs only focus on increasing knowledge, the lack of examples of firm action against adolescents who violate traffic rules, and limitations in the variety of promotional methods and media $[12,13]$.

Media can be a component of active and innovative learning strategies that facilitate intervention so that the material can be more easily understood. The effectiveness of adolescent behavior change interventions is highly dependent on the combination of appropriate intervention methods and media [13]. Social media has the potential to be an effective health promotion tool because it allows everyone to exchange information and ideas in the form of videos, images, texts, and multimedia quickly $[13,14]$. One of the most popular social media among adolescents is TikTok. This application is claimed to be a form of new freedom in creativity for online content creators. TikTok is considered essential to the development of the maturity and experience of the millennial generation who are attached and close to the digital world, which includes gadgets [15].

The purpose of this research is to analyze the results of implementing a road safety education program based on the interests and needs of adolescents. The target of the intervention is adolescents because adolescents experience dynamics in emotional and social changes. The hypothesis that was arranged at the beginning of the study is that the model intervention was able to increase the knowledge, beliefs, attitudes, intentions, and practices of driving safety for adolescents as a whole. The method and media approach adopted is aimed at reducing the obstacles experienced by stakeholders in the implementation of driving safety education programs.

\section{Materials and Methods}

\subsection{Zainafree Road Safety Education Program}

The Zainafree Road Safety Education Program, or, as it is called, the Zainafree's RSE Program, was developed based on an analysis of the need for the socialization of driving safety for high school students through an open survey for all students in Semarang. The purpose of this survey is to obtain information about the interests and needs of adolescents in receiving socialization on driving safety. Therefore, when running the program, students are enthusiastic, interested, and consistent because the program is in accordance with their interests and needs. 
The indicators for the needs survey are divided into 5 sub-needs: types and methods of socialization, socialization speakers, duration of socialization, socialization materials, and socialization media. In addition to sourcing the information from the student needs survey, we also held discussions with various sources from government institutions, such as the police, schools, universities, health offices, and transportation services that are related to the implementation of RSE. The results of the needs survey and the results of the discussions were then processed and analyzed in order to develop a design model for the Zainafree's RSE Program. The design was discussed in a focus group discussion with key parties, namely the police, schools, and universities, in order to obtain the most suitable final model to be applied to students. The final model consists of 36 TikTok videos, manual guiding, material narration via WhatsApp, pamphlets, companion manuals, lists of quizzes, and lists of questions for the program evaluation. The final model then carried out a feasibility assessment by material experts and media experts before being applied to students. The value obtained was 3.9 out of a total score of 4.0 based on the formula $\mathrm{P}=\frac{\sum \mathrm{ni}}{\mathrm{N}} \times 100 \%$. This means that the final model, called Zainafree's RSE Program, is good and feasible to be applied to adolescents.

Zainafree's RSE Program is a series of social media-based RSE consisting of: (1) interactive zoom meetings with a duration of $90 \mathrm{~min}$ with the police and the school discussing procedures for being a good driver and driving safely; (2) a short video about driving safety education using TikTok media with a discussion of various materials with students every day for 6 weeks at 04.00 p.m.(capture of TikTok video can be seen in Figure 1), after teaching and learning activities at school are completed; (3) narrative materials, posters, leaflets, and educational whatsapp stickers (can be seen in Figure 2) as a complement to educational videos; (4) group-based material discussions and accompanied by questions and answers guided by peer educators and also involving the police; (5) observing the driving behavior of students by parents and peers; and (6) evaluating the implementation of the program through quizzes every weekend-pre-test, post-test 1, and post-test 2 .

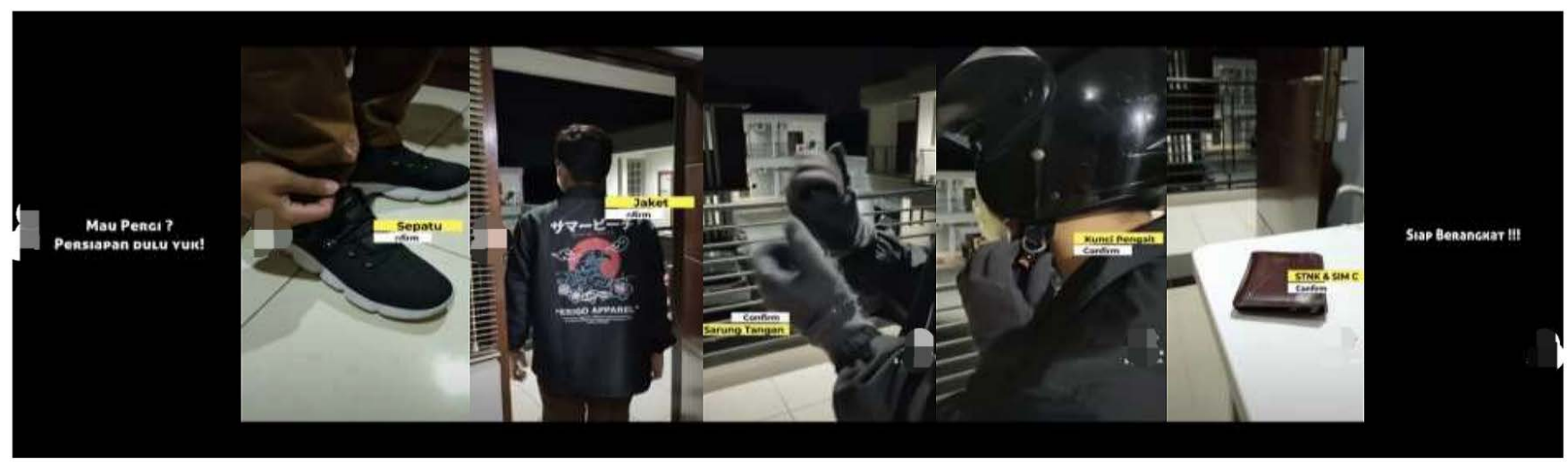

Figure 1. Capture of TikTok video in the Zainafree's RSE Program. 

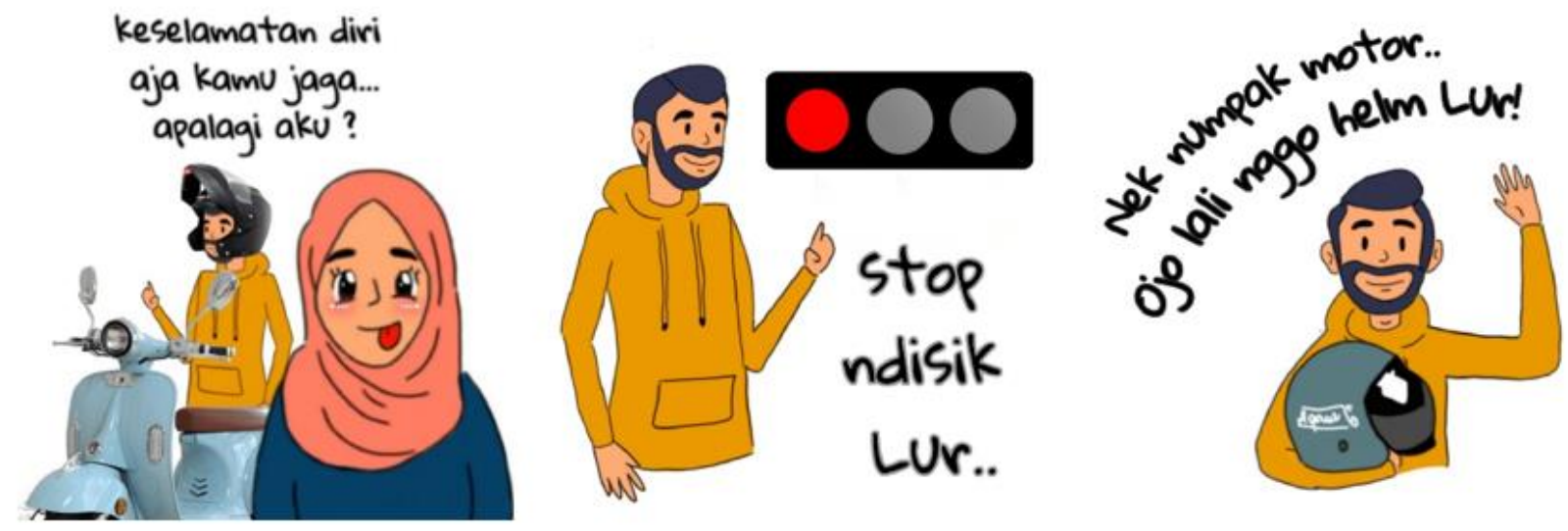

Figure 2. WhatsApp stickers in the Zainafree's RSE Program.

\subsection{Design and Data Collection}

The Zainafree program was designed then tested and has been implemented in 2021 for nine months. The program has been applied to students in Semarang, Indonesia. The design of this study was a quasi-experimental approach with a non-randomized pre-testpost-test control group design. The Zainafree's RSE Program was applied to 362 students with an intervention group of 177 students who were selected using purposive sampling technique in two schools with the same characteristics, including inclusion and exclusion criteria. The inclusion criteria in this study were: active students in two selected schools who were willing to participate in the study and signed an informed consent. The exclusion criteria for this study were students who lived outside the city of Semarang. Data were collected before being given the intervention (pre-test), after giving the intervention for 2 weeks (post-test 1), and 2 weeks after giving the intervention (post-test 2). Data were collected using a questionnaire that had been tested for validity and reliability in a limited trial of 60 adolescents in different schools with two schools that intervened.

\subsection{Measures}

The dependent variable in this study is knowledge, which is measured through 20 questions related to driving safety; then, the correct number of questions, beliefs, attitudes, and intentions are measured through a questionnaire with a Likert scale (see Supplementary Materials), including SD (strongly disagree), D (disagree), N (neutral), A (agree) and SA (strongly agree), while the behavioral variables include A (always), S (sometimes), and $\mathrm{N}$ (never). The total score of each dependent variable is included in the analysis. The independent variable is Zainafree's RSE Program.

Confounding variables are thought to cause a bias in the results of the effectiveness of the model. There was a history of receiving RSE, time to participate in socialization, the ability to ride a motorcycle, age to start driving, driving frequency, the most frequent time to ride a motorcycle, most frequent driving destinations, vehicle capacity, average speed, history of having an accident, history of consuming alcohol, history of taking illegal drugs, having a driving license, and a history of traffic violations. The collection of data on confounding variables through questionnaires answered by respondents according to their chosen category, while controlling for confounding variables, was carried out at the multivariate analysis stage.

\subsection{Statistical Analysis}

Respondents were grouped into the intervention group and the control group. The intervention group was given the Zainafree's RSE Program and supervised while the control group did not receive the program. Chi-square analysis was conducted to observe the homogeneity of the characteristics of the two groups and the distribution of the variables. Mann-Whitney analysis was conducted to observe the effect of the Zainafree's RSE Program on changes in driving safety behavior among respondents. The multivariate analysis 
through the general linear model repeated measure ANOVA (GLM-RMA) was used to determine the effectiveness of the model from various confounding factors [16].

\section{Results}

\subsection{Characteritics of Respondents}

Table 1 shows that the characteristics of respondents in the intervention group and control group are the same; out of 22 characteristics only two characteristics have a $p$ value $<0.05$, which means that the intervention and control groups are homogeneous.

Table 1. Characteristics of research respondents.

\begin{tabular}{|c|c|c|c|c|c|}
\hline \multirow{3}{*}{ Characteristics } & \multicolumn{4}{|c|}{ Group } & \multirow{3}{*}{$p$-Value } \\
\hline & \multicolumn{2}{|c|}{ Intervention } & \multicolumn{2}{|c|}{ Control } & \\
\hline & $n=177$ & $\%$ & $n=185$ & $\%$ & \\
\hline & & & & & 0.128 \\
\hline Male & 76 & 42.9 & 65 & 35.1 & \\
\hline Female & 101 & 57.1 & 120 & 64.9 & \\
\hline Have a Road Safety Education (RSE) & & & & & 0.071 \\
\hline Yes & 123 & 69.5 & 144 & 77.8 & \\
\hline No & 54 & 30.5 & 41 & 22.2 & \\
\hline Time of Receiving an RSE & & & & & 0.052 \\
\hline Never & 54 & 30.5 & 40 & 21.6 & \\
\hline$<$ Last 3 months & 26 & 14.7 & 17 & 9.2 & \\
\hline Last 3-6 months & 12 & 6.8 & 9 & 4.9 & \\
\hline Last $7-12$ months & 14 & 7.9 & 19 & 10.3 & \\
\hline >Last 1 year & 71 & 40.1 & 98 & 53.0 & \\
\hline Ability to Ride a Motorcycle & & & & & 0.392 \\
\hline Yes & 158 & 89.3 & 170 & 91.9 & \\
\hline No & 19 & 10.7 & 15 & 8.1 & \\
\hline Earliest Driving Age (Years) & & & & & 0.661 \\
\hline Yet & 19 & 10.7 & 15 & 8.1 & \\
\hline$<17$ years & 142 & 80.2 & 151 & 81.6 & \\
\hline$\geq 17$ years & 16 & 9.0 & 19 & 10.3 & \\
\hline Driving Frequency & & & & & 0.225 \\
\hline Daily & 84 & 47.5 & 87 & 47.0 & \\
\hline Twice a day & 36 & 20.3 & 31 & 16.8 & \\
\hline Once a week & 21 & 11.9 & 37 & 2 & \\
\hline Once a month & 16 & 9.0 & 15 & 8.1 & \\
\hline Most Frequent Time of Driving & & & & & 0.288 \\
\hline $06.00-11.59$ a.m. & 40 & 22.6 & 35 & 18.9 & \\
\hline 12.00-17.59 p.m. & 81 & 45.8 & 103 & 55.7 & \\
\hline 06.00-11.59 p.m. & 36 & 20.3 & 32 & 17.3 & \\
\hline 00.00-05.59 a.m. & 1 & 0.6 & 0 & 0 & \\
\hline Most Frequent Driving Locale & & & & & 0.231 \\
\hline Cannot drive & 19 & 10.7 & 15 & 8.1 & \\
\hline Neighborhood & 88 & 49.7 & 96 & 51.9 & \\
\hline Outside village & 36 & 20.3 & 32 & 17.3 & \\
\hline Inside city & 29 & 16.4 & 41 & 22.2 & \\
\hline Outside city & 5 & 2.8 & 1 & 0.5 & \\
\hline Vehicle Type & & & & & 0.202 \\
\hline$<500 \mathrm{cc}$ & 151 & 85.3 & 154 & 83.2 & \\
\hline$\geq 500 \mathrm{cc}$ & 7 & 4.0 & 3 & 1.6 & \\
\hline
\end{tabular}


Table 1. Cont.

\begin{tabular}{|c|c|c|c|c|c|}
\hline \multirow{3}{*}{ Characteristics } & \multicolumn{4}{|c|}{ Group } & \multirow{3}{*}{$p$-Value } \\
\hline & \multicolumn{2}{|c|}{ Intervention } & \multicolumn{2}{|c|}{ Control } & \\
\hline & $n=177$ & $\%$ & $n=185$ & $\%$ & \\
\hline Average Speed & & & & & 0.000 \\
\hline$<60 \mathrm{~km} / \mathrm{h}$ & 110 & 62.1 & 140 & 75.7 & \\
\hline$\geq 60 \mathrm{~km} / \mathrm{h}$ & 67 & 37.9 & 30 & 16.2 & \\
\hline Experience of RTA & & & & & 0.855 \\
\hline Yes & 72 & 40.7 & 77 & 41.6 & \\
\hline No & 105 & 59.3 & 108 & 58.4 & \\
\hline Using Alcohol & & & & & 0.617 \\
\hline Yes & 3 & 1.7 & 2 & 1.1 & \\
\hline No & 174 & 98.3 & 183 & 98.9 & \\
\hline Using Drugs & & & & & 0.306 \\
\hline Yes & 1 & 0.6 & 0 & 0.0 & \\
\hline No & 176 & 99.4 & 185 & 100.0 & \\
\hline Driving License & & & & & 0.004 \\
\hline Yes & 39 & 22.0 & 66 & 35.7 & \\
\hline No & 138 & 78.0 & 119 & 64.3 & \\
\hline Commit Traffic Violation & & & & & 0.094 \\
\hline Yes & 40 & 22.6 & 29 & 15.7 & \\
\hline No & 137 & 77.4 & 156 & 84.3 & \\
\hline
\end{tabular}

Chi-square test.

\subsection{Different Test Scores between the Intervention Group and the Control Group}

Table 2 shows that the variables of knowledge, belief, intention, and behavior have no mean difference between the intervention and control groups at the pre-test ( $p$-value $>0.05)$; only the attitude variable demonstrates an average difference. The results of the post-test 1 measurement demonstrated a difference in the average $p$-value $<0.05$ in all variables, meaning that the 2-week intervention increased knowledge, beliefs, attitudes, intentions, and driving safety behavior in the intervention group; the increase in the post-test 2 average was greater compared to post-test 1.

Table 2. Results of bivariate analysis between respondents based on time.

\begin{tabular}{|c|c|c|c|c|c|c|c|c|}
\hline \multirow{2}{*}{ Variables } & \multirow[b]{2}{*}{ Test } & \multicolumn{3}{|c|}{ Intervention Group } & \multicolumn{3}{|c|}{ Control Group } & \multirow[t]{2}{*}{$p$-Value } \\
\hline & & $n$ & Mean & SD & $n$ & Mean & SD & \\
\hline \multirow{3}{*}{ Knowledge } & Pre-test & 177 & 6.97 & 0.76 & 185 & 6.96 & 0.93 & 0.600 \\
\hline & Post-test 1 & 177 & 8.04 & 0.71 & 185 & 7.13 & 0.90 & 0.000 \\
\hline & Post-test 2 & 177 & 9.30 & 0.58 & 185 & 7.14 & 0.99 & 0.000 \\
\hline \multirow{3}{*}{ Belief } & Pre-test & 177 & 6.70 & 0.47 & 185 & 6.76 & 0.77 & 0.519 \\
\hline & Post-test 1 & 177 & 8.54 & 0.81 & 185 & 6.83 & 1.23 & 0.000 \\
\hline & Post-test 2 & 177 & 9.04 & 0.60 & 185 & 6.88 & 0.94 & 0.000 \\
\hline \multirow{3}{*}{ Attitudes } & Pre-test & 177 & 67.40 & 4.38 & 185 & 66.57 & 5.46 & 0.010 \\
\hline & Post-test 1 & 177 & 87.11 & 7.44 & 185 & 67.30 & 5.48 & 0.000 \\
\hline & Post-test 2 & 177 & 91.21 & 5.61 & 185 & 69.36 & 6.81 & 0.000 \\
\hline \multirow{3}{*}{ Intention } & Pre-test & 177 & 6.97 & 0.94 & 185 & 6.87 & 0.68 & 0.686 \\
\hline & Post-test 1 & 177 & 8.91 & 0.78 & 185 & 7.25 & 1.28 & 0.000 \\
\hline & Post-test 2 & 177 & 9.40 & 0.46 & 185 & 7.31 & 1.04 & 0.000 \\
\hline \multirow{3}{*}{ Behavior } & Pre-test & 177 & 67.60 & 6.71 & 185 & 70.04 & 9.48 & 0.153 \\
\hline & Post-test 1 & 177 & 80.84 & 9.67 & 185 & 70.97 & 8.41 & 0.000 \\
\hline & Post-test 2 & 177 & 92.54 & 9.42 & 185 & 73.37 & 11.66 & 0.000 \\
\hline
\end{tabular}




\subsection{Partial Analysis}

Figure 3 shows the results of the partial analysis on each dependent variable demonstrate that there is a linear difference between the intervention group and the control group where in all variables, the control group tends to show a stagnant line between the pre-test, post-test 1 , and post-test 2 , while the intervention group demonstrated a drastic increase in the average estimated value between the conditions of pre-test with post-test 1 and post-test 1 with post-test 2 .

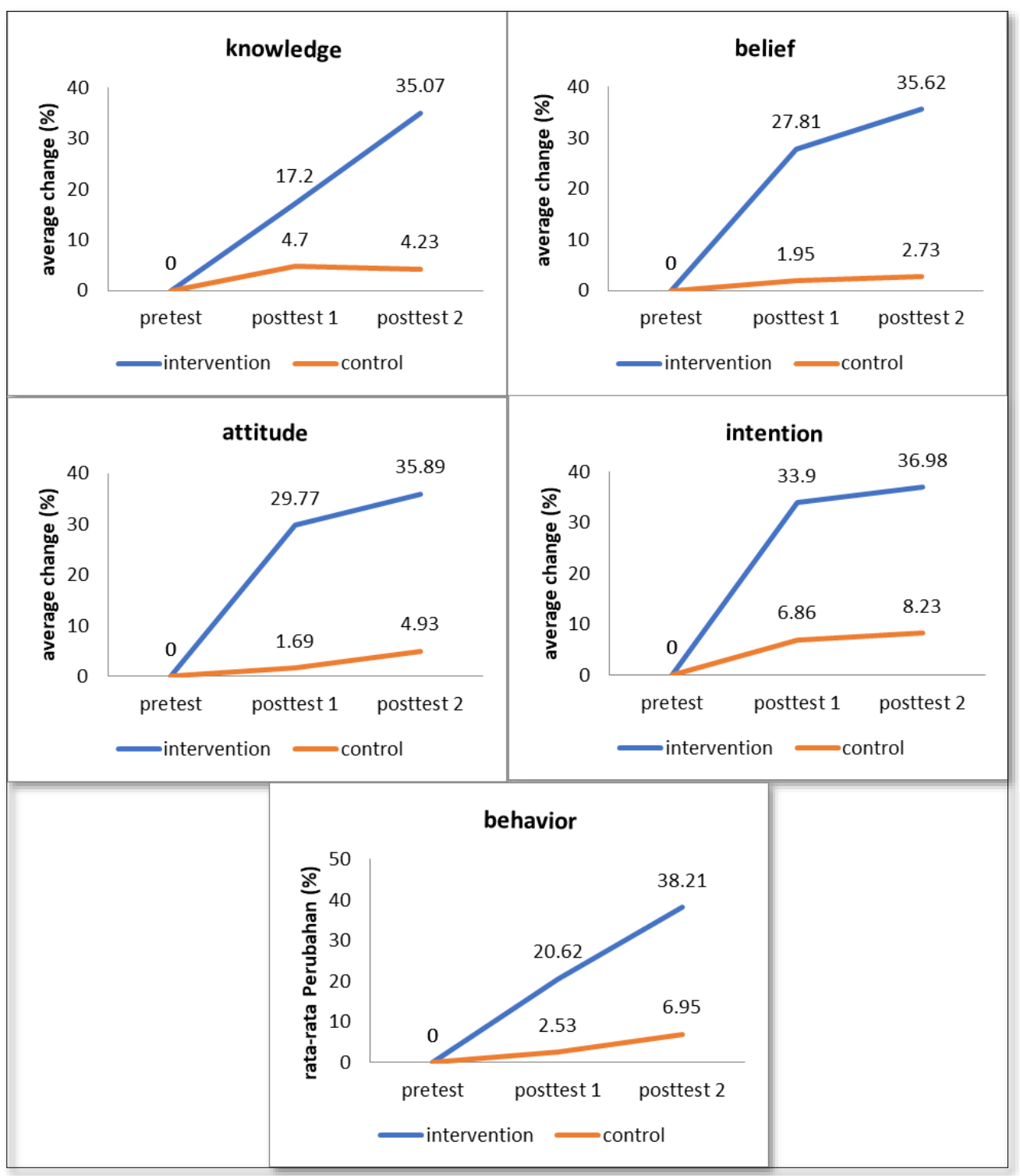

Figure 3. Partial analysis results.

3.4. The Effectiveness of the Zainafree's RSE Program on Increasing Knowledge, Beliefs, Attitudes, Intentions, and Behaviors

Table 3 shows that there are three variables that experienced a decrease in the value of the ETA Square after the adjusted involvement between confounding variables, namely, knowledge $(35.1 \rightarrow 30.6)$; attitudes $(50.9 \rightarrow 50.2)$, and behavior $(28.2 \rightarrow 26.4)$. The variables that experienced an increase in the value of the ETA Square were confidence $(32.0 \rightarrow 34.9)$ and intention $(20.7 \rightarrow 22.8)$. The highest ETA Square value is the attitude value of 50.9, meaning that after the adjusted involvement between confounding variables, 50.9 changes in the attitude value can be explained by the intervention. The results of the multivariate analysis obtained a $p$-value of 0.000 , meaning that the value is 0.05 with a $p$-value $<0.05$; 
therefore, there is a significant difference in the values of knowledge, beliefs, attitudes, intentions, and behavior combined between the intervention group and the control group after the adjusted involvement between confounding variables. The value of ETA Square 16.2 demonstrates that the intervention can explain 16.2 variations of changes that occur in the values of knowledge, beliefs, attitudes, intentions, and behavior, altogether.

Table 3. Results of the general linear analysis of the repeated measure, Anova.

\begin{tabular}{|c|c|c|c|c|c|c|}
\hline \multirow[b]{2}{*}{ Variables } & \multirow[b]{2}{*}{$p$-Value } & \multirow[b]{2}{*}{ ETA Square } & \multirow{2}{*}{$\begin{array}{l}\text { Confounding Factors } \\
\text { Included in the } \\
\text { Model (As } \\
\text { Confounding } p<0.25 \text { ) }\end{array}$} & \multirow{2}{*}{$\begin{array}{c}\text { Confounding } \\
\text { Factors Excluded } \\
\text { from the Model } \\
(p \text {-Value }>0.05)\end{array}$} & \multicolumn{2}{|c|}{ Multivariate } \\
\hline & & & & & $p$-Value & ETA Square \\
\hline Knowledge & 0.000 & 35.1 & Age & $\begin{array}{l}\text { Gender, get an RSE, } \\
\text { sleep medicine, } \\
\text { drugs, driving } \\
\text { license, parental } \\
\text { influence }\end{array}$ & \multirow{5}{*}{0.000} & \multirow{5}{*}{16.2} \\
\hline Belief & 0.000 & 32.0 & $\begin{array}{l}\text { Age, gender, sleep } \\
\text { medicine }\end{array}$ & $\begin{array}{l}\text { Get an RSE, drugs, } \\
\text { driving license, } \\
\text { parental influence }\end{array}$ & & \\
\hline Attitudes & 0.000 & 50.9 & Drugs & $\begin{array}{l}\text { Age, gender, get an } \\
\text { RSE, sleep } \\
\text { medicine, driving } \\
\text { license, parental } \\
\text { influence }\end{array}$ & & \\
\hline Intention & 0.000 & 20.7 & Age, gender, RSE & $\begin{array}{l}\text { Sleep medicine, } \\
\text { drugs, driving } \\
\text { license, parental } \\
\text { influence }\end{array}$ & & \\
\hline Behavior & 0.000 & 28.2 & Age, sleep medicine & $\begin{array}{l}\text { Gender, get an RSE, } \\
\text { drugs, driving } \\
\text { license, parental } \\
\text { influence }\end{array}$ & & \\
\hline
\end{tabular}

\section{Discussion}

Zainafree's RSE Program is an educational program for adolescents that has been designed to suit the needs and interests of adolescents in driving safety. The information about the needs and interests of adolescents was obtained from distributing questionnaires to all upper secondary students in Semarang. The data obtained are then processed to compile the Zainafree's RSE Program. Before being applied to the control group, the program was tested by experts and validated, and its reliability was measured.

Based on our knowledge, the Zainafree's RSE Program is the first road safety education research that combines five aspects at once based on the needs and interests of adolescents; the results are analyzed using the GLM-RMA. This study focuses on the combined effects of changes in knowledge, beliefs, attitudes, intentions, and driving behavior of adolescents after receiving education. The results of the final analysis demonstrate that the Zainafree's RSE Program is able to give the effect of 16.2 variations of changes that occur in all variables simultaneously. Thus, students who take part in the Zainafree's RSE Program are said to be able to reduce the risk of accident involvement compared to students who do not participate in the program. The results of the pre-test demonstrated that there was no difference in scores between the control and intervention groups. This result is motivated because half of all students have received RSE from the police in the past year; meanwhile, the results of the post-test in the intervention group experienced an increase in all variables. This demonstrates that a series of interventions have been shown to increase students' knowledge, beliefs, attitudes, intentions, and behavior in driving. 
We found that the Zainafree's RSE Program was observed to increase adolescent driving safety knowledge after receiving the intervention; this finding adds to the evidence of previous studies $[17,18]$. The program uses social media as a medium of knowledge information that can be accessed repeatedly at any time. By providing the same information frequently, the opportunity to remember, understand, and practice the information becomes greater. Someone who has received information and knowledge then builds a sense of selfconfidence that will encourage him/her to change their behavior, such as the intervention received; this is in accordance with the concepts of the Health Promotion Model and Social Cognitive Theory [19]. Likewise, the Zainafree's RSE Program and previous studies have succeeded in building adolescent self-confidence to be able to drive safely through the RSE program $[20,21]$

Adolescent attitudes that are not managed properly can increase the risk of traffic violations and increase the involvement of traffic accidents [22,23]. Therefore, the Zainafree's RSE Program has also managed adolescent attitudes and managed to get the highest results compared to other variables. The environmental management and positive attitudes from mentors and the use of media that are in accordance with the interests and needs of adolescents can be the cause of high changes in student attitudes. A health communication theory also conceptualizes those interventions that have a persuasive message and can foster a consistent attitude for behavior change [24]. This finding is in line with other studies, which found that RSE with a positive environment and companion attitude can form good young drivers' attitudes and can prevent risky driving behavior [22,23].

The other finding in this program is that social media-based interventions are proven to be effective in forming students' commitment or intention to change risky behavior while driving. In addition, the Zainafree's RSE Program has also succeeded in increasing students' self-confidence and perceptions of the benefits of driving safely. Basically, the intention to behave is based on beliefs, attitudes, and perceptions of other people's views on the behavior; this is proven in this study and in various previous studies [20,25-27]. The final goal of a health promotion is to change a person's behavior to the expected direction. The changes in behavior are based on thoughts and assessments of stimuli, such as knowledge, perception, motivation, and environmental forms [28]. This program combines various stimuli and is proven to be able to change students' driving behavior to be safer. RSE in various countries has also been proven to be successful in changing the behavior of respondents to safe driving compared to respondents who do not receive RSE; in addition, RSE can reduce the risk of being involved in traffic accidents, thus RSE interventions need to be continuously implemented and developed [29-31].

\section{Conclusions}

The Zainafree's RSE Program is a series of social media-based RSE consisting of: (1) interactive zoom with the police and the school discussing procedures for being a good driver and safe driving, (2) educational TikTok videos about safe driving every day for 6 weeks, (3) narrative material as complement videos, and (4) group discussions guided by peer educators and involving the police. The Zainafree's RSE Program intervenes at five points at once, namely, knowledge, belief, attitude, intention, and behavior. This program was proven to be effective in changing the five points; the results demonstrated that there was a change of 16.2 variations in each value together.

The advantage of this program was that all forms and media of intervention used have been prepared based on the information needs of the interests and needs of adolescents, schools, and the police; therefore, the implementation of the program is truly in accordance with the needs and desires of adolescents. The limitation of this research is that the Zainafree's RSE Program has only been implemented on a small scale, thus it is necessary to conduct trials of its implementation on a larger scale. Therefore, future research can test it on a large scale by updating the material according to its time. 
Supplementary Materials: The following supporting information can be downloaded at: https: / /www.mdpi.com/article/10.3390/safety8010012/s1.

Author Contributions: All authors contributed to the study conception and design. I.Z., study implementation, data analysis and interpretation leader, writing, editing, and manuscript review. S.H., study implementation and manuscript review. A.S., study implementation and manuscript review. B.W., data analysis, interpretation, and manuscript review. All authors have read and agreed to the published version of the manuscript.

Funding: This research received no external funding.

Institutional Review Board Statement: All subjects gave their informed consent for inclusion before they participated in the study. The study was conducted in accordance with the Declaration of Helsinki, and the protocol was approved by the Health Research Ethics Committee of Universitas Negeri Semarang (HERC number: 078/KEPK/EC/2021, 21 April 2021).

Informed Consent Statement: Informed consent was obtained from all subjects involved in the study.

Data Availability Statement: Not applicable.

Conflicts of Interest: The authors declare no conflict of interest.

\section{References}

1. Badan Pusat Statistik Indonesia. Statistik Transportasi Darat Subdirektorat Statistik Transportasi; Central Bureau of Statistics of the Republic of Indonesia: Jakarta, Indonesia, 2020; Volume 1, p. 72.

2. Kesehatan Kemenkes RI. Data dan Informasi Profil Kesehatan Indonesia Kementrian Kesehatan RI; Ministry of Health Republic of Indonesia: Jakarta, Indonesia, 2020; pp. 1-5.

3. Satlantas Polrestabes Kota Semarang. Laporan Kecelakaan Lalu Lintas Polrestabes Kota Semarang Januari-Desember Semarang; Semarang Big City Resort Police Traffic Unit: Jawa Tengah, Indonesia, 2021.

4. Bucsuházy, K.; Matuchová, E.; Zůvala, R.; Moravcová, P.; Kostíková, M.; Mikulec, R. Human factors contributing to the road traffic accident occurrence. Transp. Res. Procedia 2020, 45, 555-561. [CrossRef]

5. Gicquel, L.; Ordonneau, P.; Blot, E.; Toillon, C.; Ingrand, P.; Romo, L. Description of various factors contributing to traffic accidents in youth and measures proposed to alleviate recurrence. Front. Psychiatry 2017, 8, 94. [CrossRef]

6. Umniyatun, Y.; Nurmansyah, M.I.; Farradika, Y.; Purnama, T.B.; Hidayat, D.N. Motorcycle risky behaviours and road accidents among adolescents in Jakarta metropolitan area, Indonesia. Int. J. Inj. Control Saf. Promot. 2021, 28, 339-346. [CrossRef] [PubMed]

7. Chaudhuri, U.; Ratnapradipa, K.L.; Shen, S.; Rice, T.M.; Smith, G.A.; Zhu, M. Trends and patterns in fatal US motorcycle crashes, 2000-2016. Traffic Inj. Prev. 2019, 20, 641-647. [CrossRef] [PubMed]

8. Lastrucci, V.; Innocenti, F.; Lorini, C.; Berti, A.; Silvestri, C.; Lazzeretti, M.; Voller, F.; Bonaccorsi, G. Profiles of risky driving behaviors in adolescent drivers: A cluster analysis of a representative sample from Tuscany region (Italy). Int. J. Environ. Res. Public Health 2021, 18, 6362. [CrossRef]

9. Maulina, D. Evaluating of Police Goes to School Program in Improving Traffic Safety in West Java. J. Indones. Road Saf. 2020, 3, 21-32.

10. Yuan, Q.; Peng, Y.; Xu, X.; Wang, X. Key points of investigation and analysis on traffic accidents involving intelligent vehicles. Transp. Saf. Environ. 2021, 3, tdab020. [CrossRef]

11. Wulandari, R.; Salbiah, E.; Seran, M. Evaluasi Program Road Safety Partnership Action Police Goes to School di SMA Negeri 6 Dan Smk Pembangunan Kota Bogor. J. Gov. 2017, 3, 53-62. [CrossRef]

12. Çelik, A.; Yaman, H.; Turan, S.; Kara, A.; Kara, F.; Zhu, B. Literature Review on Effectiveness of The Use of social media A Report for Peel Public Health. J. Mater. Process. Technol. 2018, 1, 1-8.

13. Stellefson, M.; Paige, S.R.; Chaney, B.H.; Chaney, J.D. Social media and health promotion. Int. J. Environ. Res. Public Health 2020, 17, 1153. [CrossRef]

14. Allcoat, D.; Hatchard, T.; Azmat, F.; Stansfield, K.; Watson, D.; von Mühlenen, A. Education in the Digital Age: Learning Experience in Virtual and Mixed Realities. J. Educ. Comput. Res. 2021, 59, 795-816. [CrossRef]

15. Xu, L.; Yan, X.; Zhang, Z. Research on the Causes of the "Tik Tok" App Becoming Popular and the Existing Problems. J. Adv. Manag. Sci. 2019, 7, 59-63. [CrossRef]

16. Piepho, H.-P. A coefficient of determination (R (2)) for generalized linear mixed models. Biom. J. 2019, 61, 860-872. [CrossRef]

17. Alvaro, P.K.; Burnett, N.M.; Kennedy, G.A.; Min, W.Y.X.; McMahon, M.; Barnes, M.; Howard, M.E. Driver education: Enhancing knowledge of sleep, fatigue and risky behaviour to improve decision making in young drivers. Accid. Anal. Prev. 2018, 112, 77-83. [CrossRef] [PubMed]

18. Treviño-Siller, S.; Pacheco-Magaña, L.E.; Bonilla-Fernández, P.; Rueda-Neria, C.; Arenas-Monreal, L. An educational intervention in road safety among children and teenagers in Mexico. Traffic Inj. Prev. 2017, 18, 164-170. [CrossRef] [PubMed]

19. Khoshnood, Z.; Rayyani, M.; Tirgari, B. Theory analysis for Pender's health promotion model (HPM) by Barnum's criteria: A critical perspective. Int. J. Adolesc. Med. Health 2018, 32. [CrossRef] [PubMed] 
20. Huang, C.; Dannenberg, A.L.; Haaland, W.; Mendoza, J.A. Changes in Self-Efficacy and Outcome Expectations from Child Participation in Bicycle Trains for Commuting to and From School. Health Educ. Behav. 2018, 45, 748-755. [CrossRef] [PubMed]

21. Mirman, J.H.; Goodman, E.S.; Friedrich, E.; Ford, C.A. Talking with teens about traffic safety: Initial feasibility, acceptability, and efficacy of a parent-targeted intervention for primary care settings. J. Saf. Res. 2018, 66, 113-120. [CrossRef]

22. Riaz, M.S.; Cuenen, A.; Dhondt, S.; Craps, H.; Janssens, D.; Wets, G.; Brijs, T.; Brijs, K. Evaluation of a Road Safety Education Program Based on Driving Under Influence and Traffic Risks for Higher Secondary School Students in Belgium. Safety 2019, 5, 34. [CrossRef]

23. Ziakopoulos, A.; Nikolaou, D.; Yannis, G. Correlations of multiple rider behaviors with self-reported attitudes, perspectives on traffic rule strictness and social desirability. Transp. Res. Part F Traffic Psychol. Behav. 2021, 80, 313-327. [CrossRef]

24. Schiavo, R. Health Communication: From Theory to Practice, 2nd ed.; Jossey-Bass a Wiley Brand: San Francisco, CA, USA, 2013; 659p.

25. Poulter, D.R.; McKenna, F.P. Evaluating the effectiveness of a road safety education intervention for pre-drivers: An application of the theory of planned behaviour. Br. J. Educ. Psychol. 2010, 80, 163-181. [CrossRef] [PubMed]

26. Conner, M.; McEachan, R.; Lawton, R.; Gardner, P. Applying the reasoned action approach to understanding health protection and health risk behaviors. Soc. Sci. Med. 2017, 195, 140-148. [CrossRef] [PubMed]

27. Champahom, T.; Jomnonkwao, S.; Satiennam, T.; Suesat, N.; Ratanavaraha, V. Modeling of safety helmet use intention among students in urban and rural Thailand based on the theory of planned behavior and Locus of Control. Soc. Sci. J. 2019, 57, 508-529. [CrossRef]

28. Sharma, M.; Romas, J.A. Theoretical Foundations of Health Education and Health Promotion, 3rd ed.; Jones \& Bartlett Learning: Burlington, MA, USA, 2017; Volume 34, 98p.

29. Alonso, F.; Esteban, C.; Useche, S.; Colomer, N. Effect of road safety education on road risky behaviors of spanish children and adolescents: Findings from a national study. Int. J. Environ. Res. Public Health 2018, 15, 2828. [CrossRef]

30. Cutello, C.A.; Hellier, E.; Stander, J.; Hanoch, Y. Evaluating the effectiveness of a young driver-education intervention: Learn2Live. Transp. Res. Part F Traffic Psychol. Behav. 2020, 69, 375-384. [CrossRef]

31. Topolšek, D.; Babić, D.; Fiolić, M. The effect of road safety education on the relationship between Driver's errors, violations and accidents: Slovenian case study. Eur. Transp. Res. Rev. 2019, 11, 18. [CrossRef] 